\title{
Exploitation of Agricultural Land in the Czech Republic and EU Countries
}

\author{
Zdeňka Gebeltová
}

Faculty of Economics and Management, Czech University of Life Sciences in Prague, Czech Republic

\begin{abstract}
The primary objective of the paper is to assess the extent and exploitation of agricultural land in the CR and EU countries based on selected macro-socioeconomic indicators in order to determine the position of the CR and future desirable exploitation, protection and stabilisation of agricultural land in the CR.

The following methods will be employed in order to meet the objective: (1) The Coefficient of Geographical Association (CGA) and my own modified coefficients of association reflecting the impact of exploitation of agricultural land on indicators of the country's economic level. (2) Comparison (shrinkage of agricultural land, workforce in agriculture and market price of agricultural land in selected countries). (3) The Coefficient of Ecological Stability to assess the extent of stable and unstable areas in EU-27 countries. The following data are used for calculations: Eurostat (2009, 2015), World Bank and FAOSTAT (1993-2014). The extent of agricultural land in the CR (2014/1993) has been decreasing more slowly than in the detailed comparison countries ( 5 countries with the lowest CGA). The price of the agricultural land (2014) is lower than in France, Germany and Poland; nevertheless, the actual price rates are not as contrasting against these countries if purchase parity is considered. The Coefficient of Ecological Stability ranks the Czech Republic in the second half of the list of EU-27 countries ( $22^{\text {nd }}$ place). While the ecological stability of land has decreased slightly in Germany and France (2009-2015), an improvement has occurred in the CR.
\end{abstract}

\section{Keywords}

Agricultural land fund, the Coefficient of Geographical Association, agricultural land loss, the Coefficient of Ecological Stability, land price.

Gebeltová, Z. (2017) "Exploitation of Agricultural land in the Czech Republic and EU Countries", AGRIS on-line Papers in Economics and Informatics, Vol. 9, No. 4, pp. 33-44. ISSN 1804-1930. DOI 10.7160/aol.2017.090404.

\section{Introduction}

The primary objective of the paper is to assess the extent and exploitation of agricultural land in the CR and EU countries based on selected macrosocioeconomic indicators in order to determine the position of the $\mathrm{CR}$ and future desirable exploitation, protection and stabilisation of agricultural land in the CR.

Secondary objectives are to: (1) determine EU countries with natural conditions and macroeconomic results in the agricultural sector similar to those in the CR. (2) describe the development of extent and price of agricultural land with the five "most similar countries". (3) determine how ecologically stable the Czech Republic is within the EU.

According to the European Environment Agency (EEA), Europe is one of the most intensively exploited continents in the world. Its method of exploitation presents one of the fundamental causes of environmental change, which has a considerable impact on quality of life and ecosystems and on infrastructure management. However, the management of extent of agricultural land and its numerous functions - food production, nature protection, recreation and housing - is important (EEA, online 2013). The total area of agricultural land in the EU decreases in time in favour of construction and other areas, and partly even forest. In spite of the agricultural overproduction, this is a trend that different countries gradually try to prevent by means of various legislative measures, primarily because the knowledge and awareness of nonproductive functions of soils have been increasing (MoA, 2015). The shrinkage of agricultural land in the Czech Republic as a consequence of climate change is studied by Lorencová et al. (2013). 
Long-term shrinkage of agricultural land in selected areas of Poland is highlighted by Bucała-Hrabia (2017). Schwaab et al. (2017) study the rapid decrease in fertile soils in large urban areas and search for compromises that will not endanger urban development in Switzerland.

German authors (Steinhäußer et al., 2015) have found out: Within just a few years, land-use conflicts have become considerably more acute in Germany, mainly due to recent changes in the national energy policy. Land users have become much more aware that land is a limited resource, and this has led to competition among the following land-use sectors: settlements/transportation, agriculture, forestry and conservation.

Land use changes are the result of a complex interplay of drivers and processes operating at different spatial and temporal levels. Landowners play a crucial role in land use changes and are the target of many policy interventions and instruments. Yet, we lack a full understanding of the relationship between different drivers and how they influence landowners' decisionmaking processes and strategies.) Kristensen (2016). Agricultural landscapes safeguard ecosystem services (ES) and biodiversity upon which human well-being depends. However, only a fraction of these services are generally considered in land management decisions, resulting in trade-offs and societally inefficient solutions. The study indicate that the continued decrease of ES and biodiversity in Germany can be explained by implementation deficits within a well-established nature conservation system (Albert at al., 2017).

Agriculture is the largest type of land use in the UK, accounting for about 77 per cent of the total area, compared with an average 50 per cent for the EU27. It seems likely that over the next 50 years, the UK's land area will be required to deliver an increasingly diverse range of private and public goods to meet growing human needs and aspirations. This will require a balance of policy-driven goals and market forces. It will also need a much improved understanding of the trade-offs between food production and environmental goals and of the institutional arrangements required to achieve a balance of economic, social and environmental outcomes (Angus, 2009). Land use optimization is a prerequisite for sustainable development, regardless the characteristics of the zone before and after industrial intervention. The results show special need for developing artificial wetlands (42\%), followed by Agriculture $(23 \%)$ and Forestry (12\%). The results for "Do Nothing" $(23 \%)$ relate to the actual situation of the recovered zone after mining intervention with agriculture applications which had been proved to be successful in attaining Sustainable Development (Palencia-Aguilar, 2015). Agriculture is the primary land use across Europe, hence future European land use is largely a function of the activity chosen for this sector. The main driving factor that determines how agricultural land is managed is profitability (Rounsevell et al., 2003). A low profit can lead to land abandonment. Conversely a large profit can lead to forest and land that is otherwise unsuitable, being converted to agriculture. The changes in relative profit between enterprises (whether due to technology, subsidy or economics) can lead to large areas of single crops, landscapes of brightly coloured crops, and arable crops replacing permanent grassland on slopes. All these changes in agricultural land use have profound impacts on the quality of the landscape and the environment through, for example, nutrient dynamics, soil erosion, ecological diversity and food resources for birds and other wildlife. In the second half of the 20th century technology and socio-economic change have driven rapid changes in land use (Ewert et al., 2005).

The dynamic ability of ecosystems to constantly maintain and renew conditions for their existence with self-regulatory mechanisms is referred to as ecological stability of landscape. It is characterised by steadiness, resistance and flexibility to disrupting influences of both natural and anthropogenic origin. The ecological stability of a country can be regarded as a basis for assessment of all conditions and prerequisites for landscape exploitation. If a certain degree of land exploitation is exceeded, the stabilisation, recovery and production functions of soil are reduced or even halted completely. With inappropriate land management, this brings numerous risks in the form of degradation of landscape and its components (Zaušková and Midriak, 2007). Forman and Godron (1993) understand the stability of land and its resistance to disruption and its ability to recover after disruption. Vološčuk and Míchal (1991) refer to ecological stability as the ability of an ecosystem to restore its dynamic equilibrium or its "normal" development direction by means of its internal mechanisms. The faster an ecosystem recovers and the smaller deviations it shows, the more stable it is.

\section{Materials and methods}

The objective will be attained by using the following mathematical formulas, described procedure and data. 


\section{Materials}

Information about production factors (soil, labour) will be taken from the FAOSTAT database and then I will use it for the calculation of economic level indicators (for 1993-2014). Information about the division of agricultural land for the EU-27 (data from Croatia absent) will be taken from the EUROSTAT database (Land cover overview by NUTS 2 regions) for 2009 and 2015. Addition economic indicators: "Agriculture, value added (\% of GDP)" and "Employment in agriculture" will be taken from the World Bank database (2014, online 2017). Calculations will be made with data for 1993-2014 and 2015. The year 1993 corresponds to the Czech Republic's independence and the years 2014 and 2015 are the latest available years in the international databases at the time of writing.

\section{Procedure nad formulas}

The Coefficient of Geographical Association (CGA) (equation 1) will be used to determine the similarity in structure of agricultural land in EU countries. The calculation will include indicators comprising components of agricultural land (AL). The calculation consists in a sum of absolute differences of selected AL indicators between the selected country and the other compared countries. The lower the sum of differences, the greater the similarity between the countries examined. I intend to identify 5 countries with the most similar AL exploitation.

Coefficient of geographical association (CGA) by Bičík (1982):

$$
C G A=\left|\Delta K_{1}\right|+\left|\Delta K_{2}\right|+\left|\Delta K_{3}\right|+\ldots\left|\Delta K_{n}\right|
$$

Where:

$|\Delta K|=$ Absolute difference of indicators (percentage points): The Czech Republic (\%) to the comparative country $(\%)$.

$n=$ number of indicators

In addition, I intend to identify the socioeconomic consequences of AL exploitation. I will therefore modify the $C G A$ (Bičík, 1982) in my own way (equations 2, 3). Inclusion of different variables will be purely individual; and I will use my own names of the modified coefficients.

Coefficient of Basic Association (CBA) will be calculated from the following indicators: Agricultural land (\% of land area) $\left(K_{l}\right)$ and Arable land (\% of agricultural land area) $\left(K_{2}\right)$.

$$
C B A=\left|\Delta K_{1}\right|+\left|\Delta K_{2}\right|
$$

Coefficient of extended association (CEA). The coefficient of basic association will be extended with additional qualitative economic indicators: Agricultural land per capita $\left(K_{3}\right)$, Agriculture, value added (\% of GDP) $\left(K_{4}\right)$ and Employment in agriculture $\left(K_{5}\right)$ in \%.

$$
C E A=\left|\Delta K_{1}\right|+\left|\Delta K_{2}\right|+\left|\Delta K_{3}\right|+\left|\Delta K_{4}\right|+\left|\Delta K_{5}\right|
$$

Countries with the lowest results will be identified based on equations 1, 2, 3. These will be countries with similar geographical conditions, producing similar agricultural outputs based on a similar extent of production factors used (labour, soil). These countries will then be included in the detailed comparison. I will compare the annual decrease in $\mathrm{AL}$, the share of $\mathrm{AL}$ in the country area, the tilled land percentage, employment in agriculture (period 1993-2014), and the market price of agricultural land (2014). If countries with similar natural conditions attain better economic results, then there is room for improvement in the CR (e.g. size of businesses, ownership relations, shrinkage of agricultural land, amount of investment in agriculture, labour productivity, amount of subsidies received, etc.).

Effective agricultural policy should work in connection with environmental sustainability. Attention will be paid to ecological stability of landscape in the assessment of agricultural land in the EU countries. Míchal (1985) has defined the procedure for calculating the Coefficient of Ecological Stability (CES) (equation 4) and made a classification of results (Table 1 ).

$C E S=\frac{\text { forest land }+ \text { water areas and watercourses }+}{\text { arable land }+ \text { vineyards }+ \text { anthropogenic areas }+ \text { others areas }}$

Note: The CES expresses the stable areas ratio to unstable landscaping elements.

\begin{tabular}{|l|l|}
\hline $0.1<\mathrm{CES}<0.30$ & $\begin{array}{l}\text { The area is used above the average, } \\
\text { with the distinct disruption of natural } \\
\text { structures. The basic environmental } \\
\text { functions must be continually replaced } \\
\text { by the technical interventions. }\end{array}$ \\
\hline $0.3<\mathrm{CES}<1.00$ & $\begin{array}{l}\text { The intensively used area - mostly } \\
\text { by agricultural activities. The weakened } \\
\text { self-regulation processes can cause } \\
\text { an ecological lability in ecosystems. }\end{array}$ \\
\hline $1.00<\mathrm{CES}<3.00$ & $\begin{array}{l}\text { Enough balanced landscape. Technical } \\
\text { objects are relatively in compliance } \\
\text { with natural structures }\end{array}$ \\
\hline $\mathrm{CES}>3.00$ & $\begin{array}{l}\text { Nature with the strong predominance } \\
\text { of ecologically stable structures and low } \\
\text { intensity of landscape use by humans. }\end{array}$ \\
\hline
\end{tabular}

Source: Míchal (1985)

Table 1: The coefficient of ecological stability - classification (in CR). 
The international databases follow the structure of agricultural land differently from those in the CR. I will therefore modify equation 4 according to the landscape character (stable/ unstable) to yield the $\mathrm{CES}_{\mathrm{EU}}$ (equation 5).

$C E S_{E U} \frac{(\text { Woodland }+ \text { Shrubland })+(\text { Water }+ \text { Wetland })+\text { Grassland }+ \text { Bareland }}{\text { Cropland }+ \text { Artificial land }}$

Note: The limits of $\mathrm{CES}_{\mathrm{EU}}$ for inclusion of countries in categories of results are identical to those of CES Míchal (Table 1).

Source: Author by: Míchal (1985), CSO (2006) and "Land Cover" EUROSTAT

The next phase of identification of ecologically important landscape will employ equations containing weighted coefficients for different types of areas (Miklós, 1986; Löw et al., 1987). The objective is to find out how the assigned importance of cultivation influences the ranking of EU countries in the ecological assessment of landscape.

$\operatorname{CES}($ Miklós $)=\frac{p_{n} * k_{p n}}{p}$

Where $p_{n}=$ area of individual cultures, $p=$ total monitored area, $k_{p n}=$ coefficient of ecological significance: field: 0.14 , meadows: 0.62 , pastures: 0.68 , gardens: 0.5 , fruit orchards: 0.3 , forests and water: 1, other 0.1 (more in: Miklós, 1986).

$C E S(L \ddot{o} w) \frac{1.5 A+B+0.5 C}{0.2 D+0.8 E}$

Where $A=5^{\text {th }}$ grade area (best landscape: forest area, water area, wetlands, bare mountain), $B=4^{\text {th }}$ grade area (scrub/bush), $C=3^{\text {rd }}$ grade area (permanent grasslands), $D=2^{\text {nd }}$ grade area (arable land), $E=1^{\text {st }}$ grade area (worst land use: built up areas, anthropogenic areas). Units: \% (more in: Löw, 1987).

The results will then be evaluated by means of comparison. I will identify the trends in agricultural land exploitation in EU countries as well as the detailed comparison countries. The comparison will indicate the economic valuation of agricultural land and how anthropogenic interventions affect AL exploitation. These conclusions will form the input information for the follow-up research in the area of efficiency of agricultural land exploitation.

\section{Results and discussion}

The initial comparison of EU countries based on quantitative and qualitative economic indicators that are explicitly related to AL exploitation.
The Czech Republic's position within the EU27 is derived from the data shown in Table 2 (WB, FAO, 2014). The CR has an above-average share of $\mathrm{AL}$ in the national territory (+11.27 p.p.) as well as the tilled area $(+11.86$ p.p.) in relation to the EU average. In terms of agricultural land per capita, the CR has an average value within the European Union. The macroeconomic indicators describe the $\mathrm{CR}$ as a country with a lower economic importance of agricultural production. Agriculture value addend (\% of GDP) in the CR is 1.04 p.p. higher than the EU average, and Employment in agriculture is 1.95 p.p. lower than in the EU. The importance of agriculture in the Czech Republic is decreasing, its share in the GDP and employment are also decreasing (WB, 1993-2014). The technical equipment is better than in the other Central and Eastern European countries; however, the agricultural efficiency does not achieve EU-15 results (Pělucha, 2006).

The smaller EU countries of Northern and Western Europe, where the share of added value of agriculture in the GDP is below $2 \%$, are oriented to exportation of agricultural products with a high added value (Denmark, Ireland, the Netherlands). Other countries in this area do not have significant export activities (Belgium, United Kingdom, Finland, Sweden). In Finland and Sweden, the tilled land percentage is normally higher than $85 \%$. In large EU countries (France and Spain), agriculture plays a significant role and is relatively efficient (share of agriculture in GDP is $1.73 \%$ and $2.50 \%$, respectively, and the share of economically active is $2.82 \%$ and $4.24 \%$ ). These countries too belong among major exporters of agricultural commodities (FAO, 2014). South European countries (Portugal, Italy and Greece) belong among areas where agriculture is important but not efficient. Agriculture is clearly important in economically important countries of Central Europe (Germany and Austria). It is based on small-scale farms. Austria belongs among countries with a high share of ecologically farmed soil. However, both countries are importers of agricultural products (FAO, 2014).

The Baltic states have a higher share of agriculture in GDP (approx. 4\%), they have a problem with high employment in the sector (4-9\%) and they struggle with obsolete technical equipment in agriculture (ČTK, 2003). Among Central and South-Eastern European countries, agriculture is of great importance particularly in Poland, Romania and Bulgaria with a share in GDP of $3-5 \%$, while both Poland and Romania have a high employment in agriculture (11.47\% and $28.35 \%$ of economically active). The share 
of the agricultural sector in GDP of newly acceded EU countries decreased over the study years, although it is still above the $1.7 \%$ average for the EU-28 (WB, 2000-2014). More in Table 2.

Analysis of structure of agricultural land and associated macroeconomic indicators

Using the procedure of Bičík (1982) (equation 1), the analysis of structure of agricultural land found out that the agricultural land exploitation in the Czech Republic shows the greatest similarity with Poland $(C G A=4.03)$, Slovakia (5.83) and Germany $(C G A=8.32)$, as well as Bulgaria $(C G A=9.01)$ and Lithuania $(C G A=10.11)$. The countries least similar in terms of AL structure (reflection of natural conditions) are Ireland,
Slovenia, Portugal, Greece and the UK. This is generally due to the higher share of permanent grassland in agricultural land (from 76.28\% in Ireland to $49.04 \%$ in Portugal). In addition, Greece and Portugal have a higher share of permanent cultivation in AL (11.96 and 18.40\%) than the CR.

As needed for the research, equation 1 has been modified to equations 2 and 3 , in which the attention is not focused only on structure of agricultural land but on wider context derived from agricultural land exploitation.

The calculation of the Coefficient of Basic Association (CBA) (equation 2) indicates: the relative extent of agricultural land

\begin{tabular}{|c|c|c|c|c|c|}
\hline Country & $\begin{array}{l}\text { Agricultural land } \\
(\% \text { of land area) }\end{array}$ & $\begin{array}{c}\text { Tilled land } \\
\text { (\% of agricultural } \\
\text { land area) }\end{array}$ & $\begin{array}{l}\text { Agricultural land } \\
\text { per capita }\end{array}$ & $\begin{array}{l}\text { Agriculture, value } \\
\text { added ( } \% \text { of GDP) }\end{array}$ & $\begin{array}{l}\text { Employment } \\
\text { in agriculture }\end{array}$ \\
\hline & $\%$ & $\%$ & hectare & $\%$ & $\%$ \\
\hline Austria & 32.36 & 49.80 & 0.32 & 1.40 & 4.80 \\
\hline Belgium & 43.61 & 61.37 & 0.12 & 0.72 & 1.22 \\
\hline Bulgaria & 44.84 & 70.04 & 0.69 & 5.26 & 7.01 \\
\hline Croatia & 26.66 & 53.90 & 0.36 & 4.14 & 9.50 \\
\hline Cyprus & 11.69 & 73.82 & 0.09 & 2.08 & 4.43 \\
\hline Czechia & 53.46 & 74.55 & 0.40 & 2.74 & 2.75 \\
\hline Denmark & 61.25 & 92.51 & 0.47 & 1.58 & 2.48 \\
\hline Estonia & 21.54 & 66.52 & 0.74 & 3.58 & 3.85 \\
\hline Finland & 6.70 & 98.40 & 0.42 & 2.79 & 4.24 \\
\hline France & 52.39 & 63.73 & 0.43 & 1.73 & 2.82 \\
\hline Germany & 46.80 & 70.98 & 0.21 & 0.78 & 1.43 \\
\hline Greece & 61.95 & 31.80 & 0.75 & 3.72 & 13.57 \\
\hline Hungary & 57.47 & 82.38 & 0.54 & 4.70 & 4.66 \\
\hline Ireland & 63.55 & 23.69 & 0.97 & 1.46 & 5.69 \\
\hline Italy & 43.68 & 51.12 & 0.22 & 2.16 & 3.64 \\
\hline Latvia & 29.03 & 64.58 & 0.94 & 3.48 & 7.50 \\
\hline Lithuania & 45.22 & 79.60 & 1.01 & 3.79 & 9.17 \\
\hline Luxembourg & 50.58 & 47.80 & 0.24 & 0.29 & 1.40 \\
\hline Malta & 31.97 & 87.68 & 0.02 & 1.29 & 1.34 \\
\hline Netherlands & 44.27 & 56.82 & 0.11 & 1.84 & 2.11 \\
\hline Poland & 46.13 & 75.76 & 0.38 & 2.95 & 11.47 \\
\hline Portugal & 40.14 & 30.72 & 0.36 & 2.32 & 8.65 \\
\hline Romania & 58.01 & 63.47 & 0.69 & 5.34 & 28.35 \\
\hline Slovakia & 39.25 & 72.45 & 0.36 & 4.37 & 3.50 \\
\hline Slovenia & 30.34 & 29.95 & 0.30 & 2.42 & 9.57 \\
\hline Spain & 52.53 & 46.20 & 0.57 & 2.50 & 4.24 \\
\hline Sweden & 6.78 & 85.34 & 0.31 & 1.34 & 1.96 \\
\hline United Kingdom & 70.74 & 36.17 & 0.27 & 0.68 & 1.24 \\
\hline EU average & 42.19 & 62.69 & 0.46 & 1.70 & 4.70 \\
\hline
\end{tabular}

Sources: Own calculations based on FAOSTAT (2014) and WORLDBANK (2014)

Table 2: Selected economic indicators (EU, 2014). 


\begin{tabular}{|c|c|c|c|c|c|c|c|c|}
\hline \multicolumn{3}{|c|}{$\begin{array}{c}\text { Coefficient of Geographic Association } \\
\text { CGA (Bičík, 1982) }\end{array}$} & \multicolumn{3}{|c|}{$\begin{array}{c}\text { Coefficient of the Basic Association } \\
\text { CBA ( } 2 \text { indicators) }\end{array}$} & \multicolumn{3}{|c|}{$\begin{array}{l}\text { Coefficient of the Extended } \\
\text { Association CEA (5 indicators) }\end{array}$} \\
\hline \multicolumn{3}{|c|}{$\begin{array}{l}\text { Differences of EU countries } \\
\text { to the value of the Czech Republic: } \\
4.03-105.28\end{array}$} & \multicolumn{3}{|c|}{$\begin{array}{l}\text { Differences of EU countries } \\
\text { to the value of the Czech Republic: } \\
8.53-70.60\end{array}$} & \multicolumn{3}{|c|}{$\begin{array}{c}\text { Differences of EU countries } \\
\text { to the value of the Czech Republic } \\
12.99-74.95\end{array}$} \\
\hline & Country & & & Country & & & Country & \\
\hline 1 & Poland & 4.03 & 1 & Poland & 8.54 & 1 & France & 12.99 \\
\hline 2 & Slovakia & 5.83 & 2 & Germany & 10.23 & 2 & Germany & 13.70 \\
\hline 3 & Germany & 8.32 & 3 & Hungary & 11.84 & 3 & Hungary & 15.85 \\
\hline 4 & Bulgaria & 9.01 & 4 & France & 11.88 & 4 & Poland & 17.49 \\
\hline 5 & Lithuania & 10.11 & 5 & Bulgaria & 13.12 & 5 & Slovakia & 18.73 \\
\hline 23 & United Kingdom & 79.84 & 23 & Portugal & 57.15 & 23 & Greece & 63.39 \\
\hline 24 & Greece & 85.49 & 24 & Sweden & 57.46 & 24 & Portugal & 63.51 \\
\hline 25 & Portugal & 87.67 & 25 & Ireland & 60.95 & 25 & Ireland & 65.74 \\
\hline 26 & Slovenia & 89.20 & 26 & Slovenia & 67.71 & 26 & Finland & 72.16 \\
\hline 27 & Ireland & 105.28 & 27 & Finland & 70.60 & 27 & Slovenia & 74.95 \\
\hline
\end{tabular}

Note: Malta - not evaluated (incomplete information in the FAOSTAT).

Source: Own calculations based on relation (2), (3) and FAOSTAT (2014)

Table 3: Values of Coefficient of Association (2014).

in the Czech Republic (with respect to share of AL in the country's soil and conversion to AL per capita) is similar to that in Poland, Germany, Hungary, France and Bulgaria. The greatest similarity was found with Poland (difference between the two selected indicators $=8.54$ ).

The macroeconomic characteristics of agriculture, involved in the calculation of the Coefficient of Extended Association (CEA) (equation 3) confirmed the relationship between the CR and Germany, France, Hungary and Poland. The list of "similar" countries was extended by Slovakia (to the detriment of Bulgaria).

The highest $C E A$ values were against identified for Slovenia, Portugal, Ireland, Greece and Finland. These are countries with natural conditions different from those in the CR. Moreover, Portugal has a 13.32 p.p. lower share of $\mathrm{AL}$ in the national territory. Except Finland and Ireland, they are countries with a higher share of people employed in agriculture (more than $8 \%$ of economically active). Finland has a very low share of $\mathrm{AL}$ in its national territory $(6.7 \%)$ and thus the high tilled land percentage $(98.4 \%)$ makes sense. Both the employment and share of the sector in GDP in Finland are low, attesting to its high economic level.

The next comparison focused on countries with which the $\mathrm{CR}$ has similar economicgeographical indicators, i.e., a similar base for development of agricultural primary production as indicated by the calculations of the CEA (Table 4, equation 3 ).
The share of agricultural land in the total national territory of selected countries in 1993 was from $48.05 \%$ (Germany) to $65.89 \%$ (Hungary). In 2014, the lower bound of the range (Germany) decreased to $46.80 \%$, and a significant reduction occurred in Hungary (to $57.47 \%$ ). The upper and lower bounds thus converged to a range of 10.67 percentage points (p.p.).

The tilled land percentage has been traditionally high in the new EU member states (Table 2): $\mathrm{CR}=74.55 \%$, Hungary $=82.38 \%$, Poland $=75.76 \%$, Slovakia $=72.45 \%$.

The assessment of the time series (1993-2014) indicates the following. While the tilled land percentage decreased in the Czech Republic (-3.27 p.p.), it increased in France, Germany, Hungary and Slovakia. This is caused by the increasing arable land area (France, Germany) or a decrease in the arable land area lower than in the agricultural land (Hungary, Slovakia). In Slovakia the 10.63 p.p. decrease in the share of AL in its national territory (1993-2014) has been offset by the increased share of tilled land ( +8.60 p.p.). It can be said that the countries in the detailed comparison show a tendency towards reduction in the tilled land percentage to around $70 \%$ (except Hungary, which has $82.3 \%$ in 2014).

Employment in agriculture (1993-2014) has been decreasing significantly in all the studied countries. The greatest decrease has been in the CR $(-65 \%$ of agricultural employees) and Slovakia $(-66 \%)$. Significant decreases are 


\begin{tabular}{|l|c|c|c|c|c|}
\hline & $\begin{array}{c}\text { Agricultural land } \\
\text { (\% of land area) }\end{array}$ & $\begin{array}{c}\text { Tilled land } \\
\text { (\% of agricultural } \\
\text { land area) }\end{array}$ & $\begin{array}{c}\text { Agricultural land } \\
\text { per capita }\end{array}$ & $\begin{array}{c}\text { Agricultural land } \\
\text { area }\end{array}$ & $\begin{array}{c}\text { Employment } \\
\text { in agriculture }\end{array}$ \\
\hline Czechia & 0.98 & 0.96 & 0.96 & 0.98 & 0.35 \\
\hline France & 0.94 & 1.07 & 0.82 & 0.94 & 0.51 \\
\hline Germany & 0.97 & 1.04 & 0.98 & 0.97 & 0.40 \\
\hline Hungary & 0.87 & 1.06 & 0.91 & 0.87 & 0.51 \\
\hline Poland & 0.77 & 0.99 & 0.78 & 0.77 & 0.47 \\
\hline Slovakia & 0.78 & 1.13 & 0.77 & 0.79 & 0.34 \\
\hline
\end{tabular}

Source: Own calculations based on FAOSTAT $(1993,2014)$

Table 4: Baseline indicies of selected economic indicators (1993 - 2014).

also registered in Germany (-60\%) and Poland $(53 \%)$. The reasons are reductions to agricultural production, decreasing farmed areas of $\mathrm{AL}$ (see below), and increasing automation of agricultural production.

The Czech Republic shows an average annual decrease in AL $(-0.07 \%$ over the study period of 1993-2014). The stably low rates of decrease can easily be compared to the situation in Germany and France. Other countries included in the comparison show worse results (annual decrease in extent of AL from $-0.68 \%$ to $-1.28 \%$ ). The information on average annual shrinkage of agricultural land is complemented with the baseline index (2014/1993). The 19-year time series indicates that the extent of AL in Poland and Slovakia has shrunk by a significant $23 \%$ and $21 \%$, respectively (baseline index, Table 5).

\begin{tabular}{|l|c|c|}
\hline Indicator & $\begin{array}{c}\text { Average annual rate } \\
\text { of loss (1993-2014) in \% }\end{array}$ & $\begin{array}{c}\text { Baseline index of loss } \\
(2014 / 1993)\end{array}$ \\
\hline Czechia & -0.07 & 0.98 \\
\hline France & -0.25 & 0.95 \\
\hline Germany & -0.12 & 0.97 \\
\hline Hungary & -0.68 & 0.87 \\
\hline Poland & -1.28 & 0.77 \\
\hline Slovakia & -1.21 & 0.79 \\
\hline
\end{tabular}

Source: Own calculations based on FAOSTAT $(1993,2014)$

Table 5: Loss of Agricultural Land (1993-2014).

The causes of the annual shrinkage of agricultural land (Poland, Slovakia, Hungary) are the following:

Poland belongs to those EU countries with a high share of economically active people employed in agriculture (1994: 24\%, 2011: 11.47\%; WB 2014). The basis of Poland's agriculture is family farms, which are relatively "overstaffed" and, particularly during the economic crisis in 2009, rural inhabitants were willing to dissolve their farms, leave home and travel to work even to other EU countries.
- Slovakia does not have the conditions for intensive agricultural production. The country is characterised by mountainous areas with a higher share of pastures. People are leaving agriculture for other sectors of the national economy for economic reasons. Farming prefers agricultural land of better qualitative properties while other, less valuable soil is permanently afforested (VÚPOP, 2015).

- At the onset of the economic crisis, Hungary was forced by economic reasons to reduce both the rent per hectare and the extent of farmed agricultural land (1993: 65.89\%, 2009: 62.16\%, 2014: 57.47\%, WB 2014, MoA 2015).

- Besides, a common factor of shrinkage of agricultural land is the preference to extensive infrastructure construction, primarily the construction of vast logistics centres in Central and Eastern European countries (EUROSTAT, 2009, 2015).

Agricultural land in the $\mathrm{CR}$ is losing both its quality and utility value (effects of water and wind erosion, floods, intensive droughts and farming methods). The reduced quality of soil is reflected in the reduced official price of soil in the CR's cadastral areas (MoA, 2015). The average market price of agricultural land grew by approx. 7\% year-on-year in 2009-2014 (IQ Fund Management In: Daniel, 2015).

In comparison with the old EU-15 countries, the Central and Eastern European countries have lower agricultural land prices (MoA, 2015; Daniel, 2015). The international comparison is made based on marked prices of land in the national currency adjusted for the exchange rate (Sklenička et al., 2013; MoA, 2015). Table 6 shows the comparison of AL prices with respect to domestic population income (net income of selected economic category of population in EUR/year). 


\begin{tabular}{|c|c|c|c|c|c|c|}
\hline & $\begin{array}{l}\text { Agricultural } \\
\text { land price }\end{array}$ & $\begin{array}{l}\text { Net income } \\
\text { of selected } \\
\text { group of } \\
\text { inhabitants }{ }^{1)}\end{array}$ & $\begin{array}{l}\text { Agricultural } \\
\text { land price ratio } \\
\text { between the } \\
\text { selected EU } \\
\text { countries and the } \\
\text { Czech Republic }\end{array}$ & $\begin{array}{l}\text { Annual income } \\
\text { ratio of selected } \\
\text { EU countries } \\
\text { to the Czech } \\
\text { Republic }\end{array}$ & $\begin{array}{l}\text { Agricultural land } \\
\text { price ratio of the } \\
\text { selected country to } \\
\text { the Czech Republic } \\
\text { (by purchasing } \\
\text { power) }\end{array}$ & $\begin{array}{l}\text { Affordable } \\
\text { agricultural land } \\
\text { area according } \\
\text { to the net income } \\
\text { of residents }\end{array}$ \\
\hline & EUR/ha & EUR/year & & & & hectares \\
\hline Czechia & 5070 & 8675 & & & & 1.71 \\
\hline Germany & 18099 & 27662 & 3.57 & 3.19 & 1.12 & 1.53 \\
\hline France $^{2)}$ & 5910 & 26578 & 1.17 & 3.06 & 0.38 & 4.50 \\
\hline Poland & 5706 & 7994 & 1.13 & 0.92 & 1.22 & 1.40 \\
\hline Slovakia $^{3)}$ & 4100 & 8034 & 0.81 & 0.93 & 0.87 & 1.96 \\
\hline Niederland & 53000 & 33237 & 10.45 & 3.83 & 2.73 & 0.63 \\
\hline
\end{tabular}

Note: ${ }^{1)}$ Net income after taxes in EUR (Single person at 100\% of average earnings, no child). Exchange rate for $2014: 1$ $E U R=27.533$ CZK. Source: OECD, Pepersonal income tax rate (2014). ${ }^{2)}$ Source: MoA, 2015. ${ }^{3)}$ The selected districts of the Slovakia, Source: Budaj, S̆. et al. (2015).

Source: IQ fund management (2015), Kursy. CZ (2014), unless otherwise defined herein.

Table 6: Comparison of market prices of agricultural land in the Czech Republic and selected EU countries (2014).

The prices of agricultural land are 3.57 times higher in Germany than in the CR, 1.17 times in France, and 1.13 times in Poland (Table 6). The prices are 1.24 times lower in Slovakia than in the CR. For information, the AL price in the Netherlands is shown, which is 10.45 times higher than in the CR (2014). In terms of purchase parity of domestic population (selected category), the situation is as follows: With the exception of France and Slovakia, purchase of agricultural land is more financially demanding for the other domestic inhabitants in Germany, Poland and the Netherlands. For example, Land in Germany is more than 3 times as expensive as in the CR, but purchasing AL in Germany is only 1.12 more expensive for German citizens than it is for Czechs in the CR. In the CR (limited to selected population category), 1.73 ha can be purchased for the net annual income; it is 1.53 ha in Germany (Table 6). It cannot be supposed that it is necessary to equalise the prices of $\mathrm{AL}$ in the CR to, e.g. the German level without the countries' income levels equalising as well.

The proportion of the rent price to the market price of agricultural land (\%) is from 2\% (Germany) to $-4 \%$ (Lithuania). The proportion of the rent price and the market price of AL in the CR was $2.39 \%$ (EUROSTAT, 2009).

This paper is not unique with its contents. Similarity of natural and agricultural conditions between different countries can be found, e.g. in Ciutacu et al. (2015). They emphasise differences and similarities between the European model of agricultural and rural development and Romania's agricultural sector. Studying the extent of AL is also still an up-to-date issue.
In the long term, shrinkage of agricultural land in the CR has been identically pointed out, e.g. by Bičík et al. (2000), Němec (2004), Ministry of the Environment (CENIA, 2013) and Ministry of Agriculture (MoA, 2015). The extent and exploitation of AL in Europe has been studied with similar results, e.g., by the European Environment Agency (EEA, 2013) and others (Lorencová et al., 2013; Bucała-Hrabia, 2017; Schwaab et al., 2017; Steinhäußer et al., 2015).

\section{Assessment of agricultural land in EU countries} by coefficient of ecological stability

For landscape to be able to withstand major and minor change (stress, loading, etc.), it has to achieve a certain level of ecological stability. According to available data from the FAOSTAT for 2009 and 2015, The Czech Republic has $C E S_{E U, \text { Czechia }}=1.64$ and 1.73 (methodology, equation 5) and is thus within the medium interval of $C E S$ classification $\left(1<C E S_{E U}<3\right.$; Table 1$)$. The Czech Republic's position is below average in this land assessment ( $22^{\text {nd }}$ place, 2015).

The lowest $C E S_{E U}$ (2015) values in the EU were given to three countries (Malta, Denmark and Hungary). Malta and Denmark were in the third (negative) zone (Table 7), which shows a tendency for ecologically and naturally unstable exploitation of land. Hungary only exceeded the threshold for unstable areas $\left(C E S_{E U}=1\right)$ only very slightly $\left(C E S_{E U, \text { Hungary }}=1.09\right)$. The above countries have high tilled land percentages (ranging from 92.51 to $82.38 \%$; Table 2). In addition, Denmark and Hungary have a significant share of agricultural land in the national territories $(61.25 \%$ and $57.47 \%$, respectively). The majority of the countries 
(15 of the EU-27) are in the medium zone (places 12 - 26). The ecological stability values for the EU-27 (Table 7) are ranked from the best at 16.23 (Sweden) for the worst at 0.74 (Hungary). The $C E S_{E U}(2015)$ value equals 2.78 .

The detailed comparison again focuses on the following countries: Hungary, Poland, Slovakia, Germany and France. Among these countries, the $C E S_{E U}$ indicates that least ecologically stable is Hungary (Cropland $=43.7 \%$ of the territory). Germany among the other countries is rated better than Hungary $\left(C E S_{E U}\right.$, Germany $=1.52$, Cropland $=32 \%$ of the territory). The position of the CR ( $22^{\text {nd }}$ place $)$ is very similar to that of Poland ( $21^{\text {st }}$ place). France is $18^{\text {th }}$; Slovakia is in the 13th place. France has extensive permanent grassland areas (approx. 27\% of its territory), while Slovakia has extensive forest areas (45\% of its territory) (EUROSTAT, 2015).

Between 2009 and 2015, a positive change is shown in the CR (0.9 increase in CES), Hungary $(+0.11)$ and Poland $(+0.13)$. The primary reason for the CES increase was the reduced share of cropland in the national territory: CR (-1.6 p.p.), Hungary (-1.97 p.p.) and Poland (-2.1 p.p.) (EUROSTAT, 2009, 2015). The share of unstable areas (built-up areas) increased the most in Germany (+0.6 p.p.) and France $(+0.3$ p.p.), which led to a slight decrease in the CES (Table 7) with a stable share of cropland.

It has to be noted that the CES assessment is based on statistical classification of exploitation of surfaces of different countries. Ecological stability should reflect how land cover is exploited qualitatively (land use). Modification of the CES has been studied, e.g., by Miklós (1986) or Löw (1986). Instead of distinguishing among relatively stable and unstable areas, Miklós differentiates among their ecological importance by implementing numerical coefficients for different AL crops (equation 6). Another variation of the CES can be found in Löw (Agroprojekt, 1986), which classifies elements into categories based on the degree of element quality (equation 7). The use of weighted coefficients in CES calculations has mostly not brought better quality results. I in fact believe that the negative impacts of the share of some areas (arable land, built-up areas) on ecological stability (e.g. in the Netherlands, Ireland and Luxembourg) were overestimated.

The CES values (regional average) in the CR in 2006 ranged from 0.66 (areas with a high share of arable land) to 2.18 (high share of permanent grassland and forest land) (CSO, 2006). The CES values in the $\mathrm{CR}$ regions increased in 2015. They ranged from 1 to 2.6 (CVUT, $2015 \mathrm{In}$ : MENDELU, 2016). The growing trend in the CES results is positive. In this paper, I apply the CES calculation procedure according to Míchal (ratio of stable and unstable areas). Another procedure is a difference between these variables, and the maximum result is the optimum (CSO, 2005). The CES calculation has become one of the methodological tools for implementation of principles of the European Landscape Convention (Strasbourg, 2004 In: COE, 2017) in principles of regional spatial development. Conditions

\begin{tabular}{|c|c|c|c|c|c|c|c|c|c|}
\hline & & $\begin{array}{c}\text { CES (EU) } \\
2015\end{array}$ & $\begin{array}{c}\text { CES (EU) } \\
2009\end{array}$ & & & & $\begin{array}{c}\text { CES (EU) } \\
2015\end{array}$ & $\begin{array}{c}\text { CES (EU) } \\
2009\end{array}$ & \\
\hline 1 & Sweden & 16.23 & 15.89 & \multirow{7}{*}{ 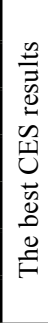 } & 15 & Italy & 2.12 & 2.06 & \multirow{10}{*}{ 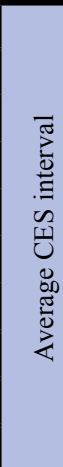 } \\
\hline 2 & Finland & 12.34 & 12.25 & & 16 & Lithuania & 2.10 & 2.71 & \\
\hline 3 & Ireland & 9.34 & 10.64 & & 17 & Luxembourg & 2.02 & - & \\
\hline 4 & Slovenia & 6.81 & 7.77 & & 18 & France & 1.92 & 1.94 & \\
\hline 5 & Estonia & 5.47 & 6.54 & & 19 & Romania & 1.91 & - & \\
\hline 6 & Latvia & 5.28 & 6.40 & & 20 & Netherlands & 1.75 & 1.89 & \\
\hline 7 & Portugal & 4.87 & 4.40 & & 21 & Poland & 1.73 & 1.60 & \\
\hline 8 & Greece & 4.33 & 3.97 & \multirow{7}{*}{ 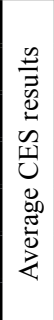 } & 22 & Czechia & 1.73 & 1.64 & \\
\hline 9 & Austria & 4.12 & 4.15 & & 23 & Germany & 1.52 & 1.56 & \\
\hline 10 & Spain & 3.04 & 2.87 & & 24 & Belgium & 1.50 & 1.73 & \\
\hline 11 & Cyprus & 3.04 & - & & 25 & Hungary & 1.09 & 0.98 & \multirow{3}{*}{ 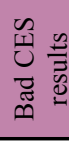 } \\
\hline 12 & United Kingdom & 2.80 & 2.82 & & 26 & Malta & 1.00 & 0.68 & \\
\hline 13 & Slovakia & 2.38 & 2.39 & & 27 & Denmark & 0.74 & 0.82 & \\
\hline 14 & Bulgaria & 2.22 & - & & & Total & 2.78 & 2.42 & \\
\hline
\end{tabular}

Note: (-) absence of data in the EUROSTAT

Source: Author by Míchal (1985), EUROSTAT(2015, 2009) and classification by Míchal (1985) - Table 1 .

Table 7: Results of $\mathrm{CES}_{\mathrm{EU}}(2015,2009)$. 
for improvement of landscape protection can also be created based on the CES results (Maier, 2012). According to Pešout and Hošek (2013), studying the CES is important from the point of view of design of flood and erosion prevention measures, which may promote environmental biodiversity.

\section{Conclusion}

In terms of structure of agricultural land (Bičík, 1982), the Czech Republic compares well with Poland, Germany, Bulgaria, Lithuania and Hungary. I applied the calculation principle according to Bičík to a wider range of macroeconomic indicators. It follows from a modification of the calculation (equation 3 ) that the $\mathrm{CR}$ has agroeconomic results similar to Germany, France, Poland, Hungary and Slovakia. My calculations indicate that the average annual decrease in AL (1993-2014) does not exceed 0.1\% (approx. 14 hectares a day; FAO, 2003-2014). The Czech Republic shows better results than France (-0.25\% p.a.), Germany (- $0.12 \%$ p.a.), Hungary (-0.68 p.a.), Poland (-1.28\% p.a.) and Slovakia (-1.21\% p.a.) (Table 5$)$. In addition, it can be concluded that the countries examined in the detailed comparison show a tendency towards a tilled land percentage to around 70\% (except Hungary, which has $82.3 \%$ in 2014). The greatest decrease in employment in agriculture has been in the CR (-65\% of agricultural employees) and Slovakia $(-66 \%)$. The reason is the narrower agricultural production, great labour and time demand, decrease in farmed AL, and increasing use of machinery in farming. The comparison of market prices of agricultural land found out that land is cheaper for the nationals, e.g. in France. Purchasing a hectare of AL in France is 0.38 cheaper than in the CR. This means that the attainable size of agricultural land from the net annual income of a French national is 2.63 larger than in the CR. However, the price of soil in France is 1.17 time higher for a CR national (Table 6). The paper thus expands on the outcomes of MoA (2015) and IQ fund management (2015).

In addition, my calculations show that: The CR is in the lower half of the list of the EU-27 countries in 2015 based on the CES (Míchal, 1986) $\left(C E S_{E U, \text { Czechia }}=1.73,22^{\text {nd }}\right.$ place $)$. Between 2009 and 2015, a positive change is shown in the CR (0.9 increase in CES), Hungary $(+0.11)$ and Poland $(+0.13)$. The application of modified CES (equations 6, 7) yielded no major results. The ecological stability of land has decreased slightly in Germany and France (2009-2015).

The $C E A$ results (equation 3 ) rate the $\mathrm{CR}$ among geographically similar and socioeconomically important countries of Western Europe (France, Germany). The price of the agricultural land is derived, and will be in future, from the price of production and, most importantly, from the added value generated by the land. This provides a potential room for future research - in the area of economic efficiency of the soil as a production factor.

\section{Corresponding author:}

Ing. Zdeňka Gebeltová, Ph.D.

Department of Economics, Faculty of Economics and Management

Czech University of Life Sciences in Prague, Kamýcká 129, 16500 Prague - Suchdol, Czech Republic

E-mail: gebeltova@pef.czu.cz

\section{References}

[1] Albert, K., Schröter-Schlaack, Ch., Hansjürgens, B., Dehnhardt, A., Döring, R., Job, H., Köppel, J., Krätzig, S., Matzdorf, B., Reutter, M., Schaltegger, S., Scholz, M., Siegmund-Schultze, M., Wiggering, H., Woltering, M. and Haaren, CH. (2017) "An economic perspective on land use decisions in agricultural landscapes: Insights from the TEEB Germany Study", Ecosystem Services, Vol. 25, pp. 69-78, June 2017. ISSN 2212-0416. DOI 10.1016/j.ecoser.2017.03.020.

[2] Angus, A., Burgess, P. J., Morris, J. and Lingard, J. (2009) "Agriculture and land use: Demand for and supplyof agricultural commodities, characteristics of the farming and food industries, and implicationsfor land use in the UK", Land Use Policy, Vol. 26, Suppl. 1, pp. S230-S242. ISSN 0264-8377. DOI 10.1016/j.landusepol.2009.09.020.

[3] Bičík I. (2000) "Hodnocení využití ploch Česka“ (In Czech), In. LUCC, (2008), Nov. 2016. [Online]. Available: https://web.natur.cuni.cz/ ksgrrsek/lucc/index.php?scn=1 [Accessed: 16 Nov. 2016]. 
[4] Bičík, I. (1982) "Ekonomická geografie I“ (In Czech), Geografie zemědělství. Science Faculty of Charles University, SPN, Prague, 105 p.

[5] Bucała-Hrabia, B. (2017) "Long-term impact of socio-economic changes on agricultural land use in the Polish Carpathians", Land Use Policy, Vol. 64, May 2017, pp. 391-404. ISSN 0264-8377. DOI 10.1016/j.landusepol.2017.03.013.

[6] Budaj, Š. et al. (2016) „Transactions With Agricultural Land in 2014 and the impact of land consolidation on land market", Economics of Agriculture, Vol. 16, No. 2., pp. 22-43. ISSN 1338-6336.

[7] CENIA (2013) "Multimediální ročenka životního prostředi" [Online]. 2014, Available: Http://www.vitejtenazemi.cz [Accessed: 17 Nov.2015].

[8] Ciutacu, C., Chivu, L. and Andrei, J. V. (2015) „Similarities and dissimilarities between the EU agricultural and rural developmentmodel and Romanian agriculture. Challenges and perspectives“, Land Use Policy, Vol. 44, March 2015, pp. 169-176. ISSN 0264-8377. DOI 10.1016/j.landusepol.2014.08.009.

[9] COE (2017) "The European Landscape Convention", Council of Europe, 2017 [Online]. Available: https://www.coe.int/en/web/landscape/home [Accessed: 10 Oct. 2017].

[10] CSO (2005) "Ekologická stabilita krajiny v roce 2005" (Ecological stability of the landscape in 2005), Czech Statistical Office, May 2009 [Online]. Available: https://www.czso.cz/csu/xl/030703406 [Accessed: 23 Sep. 2017].

[11] CSO (2006) "Koeficient ekologické stability" (In Czech), CzSO, Dec. 2007. [Online]. Available: https://www.czso.cz/csu/czso/13-1134-07-2006-3_3_1_puda [Accessed: 10 Oct 2017].

[12] ČTK (2003) "Pobaltským zemím způsobuje problémy zastaralé zemédělstvi" (In Czech), Sep.2003. [Online]. Available: http://www.ceskenoviny.cz/zpravy/pobaltskym-zemim-zpusobuje-problemyzastarale-zemedelstvi/12209 [Accessed: 25 May 2016].

[13] EEA (2013) "Využivání půdy“ (in Czech), Jul. 2014 [Online]. Available: http://www.eea.europa.eu/ cs/themes/landuse/intro [Accessed: 10 Feb 2016].

[14] EEA (2013) "Land use", European Environment Agency, Jul. 2015. [online]. Available: http://www.eea.europa.eu/cs/themes/landuse/intro, [Accessed: 10 Feb 2015].

[15] EUROSTAT (2009, 2015) „Land cover“, Jul. 2017. [Online]. Available: http://appsso.eurostat. ec.europa.eu/nui/show.do [Accessed: 20 Feb 2016].

[16] Ewert, F., Rounsevell, M. D. A. Reginster, I. R. Metzger, M. J. and Leemans, R. (2005) "Future scenarios of European agricultural land use: I. Estimating changes in crop productivity", Agriculture, Ecosystems \& Environment, Vol. 107, No. 2-3, pp. 101-116. ISSN 0167-8809. DOI 10.1016/j.agee.2004.12.003.

[17] FAO (1993-2014) "Land use". FAO STAT, Dec. 2016. [Online]. Available: http://www.fao.org/ faostat/en/\#data/RL [Accessed: 20 Sep 2017].

[18] Forman, R. T. T., Gordon, M. (1993) "Krajinná ekologie“. Prague: Academia, 583 p. ISBN 80-200-0464-5.

[19] IQ fund management (2015) In: Daniel, P. "Zemědělská půda - opomíjená investice, která se může stát lákadlem", Oct. 2015. [Online]. Available: https://www.patria.cz/zpravodajstvi/3037911/ zemedelska-puda--opomijena-investice-ktera-se-muze-stat-lakadlem.html. [Accessed: 12 Sep 2017].

[20] KES (2016) Brno: MENDELU, [Online]. Available: https://is.mendelu.cz/eknihovna/opory/781/ Knihovna\%20k\%20projektu/ekolog_stabilita_vzorce_cvut.pdf [Accessed: 29 July 2016].

[21] Kristensen, S. B. P. (2016) “Agriculture and landscape interaction - landowners' decisionmaking and drivers of land use change in rural Europe", Land Use Policy, Vol. 57, pp. 759-763. ISSN 0264-8377. DOI 10.1016/j.landusepol.2016.05.025. 
[22] Lorencová, E., Frélichová, J., Nelson, E. and Vačkář, D. (2013) "Past and future impacts of land use and climate change on agricultural ecosyste services in the Czech Republic", Land Use Policy, Vol. 33, July 2013, pp. 183-194. ISSN 0264-8377. DOI 10.1016/j.landusepol.2012.12.012.

[23] Löw, J. (1984) “Zásady pro vymezování a navrhování územních systémů ekologické stability v územně plánovací praxi” (In Czech), Brno, Agroprojekt.

[24] Maier, K. (2012) „Udržitelný rozvoj území“ Grada Publishing, ISBN 978-80-247-4198-7.

[25] Míchal, I. (1985) "Ekologický plán ČSR” In: Míchal, I. "Ekologická stabilita", 2, Brno: Veronica, 1994. 276 s. ISBN 80-85368-22-6.

[26] Miklós, L. (1986) “Stabilita krajiny v ekologickom genereli SSR”. In: Životné prostredie, Vol. 20, No 2, pp. 87 - 93 .

[27] MoA (2015) "Report on the state of agriculture 2015" (In Czech), The Ministry of Agriculture of the Czech Republic, Prague, Aug 2016. [Online]. Available: http://eagri.cz/public/web/mze/ ministerstvo-zemedelstvi/vyrocni-a-hodnotici-zpravy/zpravy-o-stavu-zemedelstvi/ [Accessed: 20 Feb 2017].

[28] Němec, J (2004) "Pozemkové právo a trh půdy v České republice“, IAEI Prague, pp. 391. ISBN 80-86671-12-7.

[29] OECD STAT (2014) "Taxing Wages - Comparative tables“, OECD, Oct. 2017. [Online]. Available: https://stats.oecd.org/Index.aspx?DataSetCode=AWCOMP [Accessed: 10 Oct 2017].

[30] Palencia-Aguilar, C. I. (2015) “Optimal Land Use at Developing Communities", Procedia Engineering, Vol. 107, pp. 430-451. ISSN 1877-7058. DOI 10.1016/j.proeng.2015.06.102.

[31] Pělucha M. (2006) "Rozvoj venkova v programovacím obdobi 2007-2013 v kontextu reforem SZP $E U^{\prime \prime}$ (In Czech), IREAS, ISP, Prague, 2006, ISBN 80-86684-42-3.

[32] Pešout P. and Hošek, M. (2012) "Ekologická sít’ v podmínkách ČR" (Ecological network in the Czech Republic), The Nature Conservation Journal, Prague, ISSN 1210-258X.

[33] Rounsevell, M. D. A., Annetts, J. E., Audsley, E., Mayr, T. and Reginster, I. (2003) "Modelling the spatial distribution of agricultural land use at the regional scale", Agriculture, Ecosystems \& Environment, Vol. 95, No. 2-3, pp. 465-479. ISSN 0167-8809. DOI 10.1016/S0167-8809(02)00217-7.

[34] Schwaab, J., Deb, K., Goodman, E., Lautenbach, S., Strien, M. and Grêt-Regamey, A. (2017) "Reducing the loss of agricultural productivity due to compact urban development in municipalities of Switzerland", Computers, Environment and Urban Systems, Vol. 65, p.p. 162-177. ISSN 0198-9715. DOI 10.1016/j.compenvurbsys.2017.06.005.

[35] Sklenicka, P., Molnarova, K., Pixova, K., C. and Salek, M. E. (2013) "Factors affecting farmland prices in the Czech Republic", Land Use Policy, Vol. 30, No. 1, pp. 130-136. ISSN 0264-8377. DOI 10.1016/j.landusepol.2012.03.005.

[36] Steinhäußer, R., Siebert, R., Steinführer, A. and Hellmich, M. (2015) "National and regional land-use conflicts in Germany from the perspective of stakeholders", Land Use Policy, Vol. 49, pp. 183-194. ISSN 0264-8377. DOI 10.1016/j.landusepol.2015.08.009.

[37] Vološčuk, I. and Míchal, I. (1991) "Rozhovory o ekológii a ochrane př́rody“, Enviro Martin, 162 s. ISBN 8085458012.

[38] WB (1993 - 2014) “World development indicators", World Bank, Feb. 2017 [Online]. Available: http://databank.worldbank.org/data/reports.aspx?source=world-development-indicators [Accessed: 5 Sep. 2017].

[39] Zaušková, L'. and Midriak, R. (2007) „Únosnost’ a využivanie krajiny“, Banská Bystrica, FPV UMB, 2007. ISBN 978-80-8083-543-9. 